\title{
Users' perception of actions, improvement in quality of life and satisfaction with the Academia da Cidade Program
}

\author{
Percepção das usuárias a respeito das ações, melhoria da qualidade de \\ vida e satisfação com o Programa Academia da Cidade
}

\begin{abstract}
Wallacy Milton do Nascimento Feitosa 1,2,6, Flávio Renato Barros da Guarda1,3,6, Lisandra Maria Konrad4, Widjane Sheila Ferreira Gonçalves², Petrônio José de Lima Martelli5, José Luiz do Amaral Correia de Araújo Júnior
\end{abstract}

\begin{abstract}
The purpose of this study was to analyze the perception of the users of the Academia da Cidade Program in Recife, Northeastern Brazil, regarding their satisfaction with the provision of services and perception of changes linked to quality of life after joining this program. Therefore, a case study with a qualitative approach was performed. The study subjects were 28 users aged between 28 and 73 years, selected intentionally, using the criterion of saturation and diversity of centers. Data collection was carried out from August to December 2014. The gathering of meanings proposed by Kvale was the method used to analyze the interviews. Lack of materials, time and type of activities were the complaints made by users. The perception of changes associated with quality of life was observed through the perception of improvement in health, the pleasure of physical activity, social interaction and good relationship with the professionals involved in the Academia da Cidade Program - Recife. It was concluded that one of the fundamental aspects of quality of service refers to the satisfaction of its users and the quality of satisfaction that produces effective and positive effect on their quality of life.
\end{abstract}

\section{Keywords}

Health Programs; Physical Activity; Health Services; Qualitative Research.

\section{Resumo}

O objetivo desta investigação foi analisar a percepção das usuárias do Programa Academia da Cidade do Recife quanto a satisfação com a oferta de serviços e percepção de mudanças ligadas à qualidade de vida após a entrada no programa. Para tanto, realizou-se um estudo de caso, com abordagem qualitativa, com 28 usuáriasde 28 a 73 anos de idade, selecionadas de forma intencional, mediante o critério da saturação e de diversidade de polos. A coleta de dados foi realizada no período de agosto a dezembro de 2014. A condensação de significados proposta por Kvale foi o método utilizado para análise das entrevistas. A falta de materiais, tempo e $o$ tipo de orientação das atividades foram as insatisfações apontadas pelas usuárias. A percepção de mudanças ligadas à qualidade de vida se deu por meio da percepção de melhora na saúde, o prazer pela prática da atividade física, o convívio social e o bom relacionamento com os profissionais envolvidos no Programa Academia da Cidade de Recife. Conclui-se que um dos aspectos fundamentais da qualidade de um serviço refere-se à satisfação de seu usuário e na qualidade do que essa satisfação produz efetiva e positivamente na sua qualidade de vida.

\section{Palavras-chave}

Programas de saúde; Atividade física; Serviços de saúde;Pesquisa qualitativa.

\section{Introduction}

The availability of physical activity programs for the community has significantly increased in Brazil. This

1 Oswaldo Cruz Foundation/ Aggeu Magalhães Research Center - Center of Studies on Collective Health - Recife, PE, Brazil

2 Asces Faculty - Public Health Research Group

3 Federal University of Pernambuco - Vitória Academic Center - Vitória de Santo Antão, PE, Brazil

4 Federal University of Santa Catarina - Sports Center - Florianópolis, SC, Brazil 5 Universidade Federal de Pernambuco - Department of Social Medicine - Recife, PE, Brazil

6 Health and Lifestyle Research Group - GPES/UPE is certainly the result of a change in awareness of public management to define policies that promote this type of initiative ${ }^{1}$. However, if these policies are to be more effective, apart from the aspects associated with individual attributes such as interest, social support and self-efficacy, access to spaces and locations for practice is also required, such as parks and squares ${ }^{2}$.

Among the initiatives developed to promote physical activity in Brazil, the Academia da Cidade Program of the city of Recife (ACP Recife) aims to pro- 
vide programs of free guidance on physical exercises, to promote the adoption of healthy eating habits and social contact through recreational and leisure activities, and to provide specific guidance for hypertensive and diabetic individuals and those with chronic diseases ${ }^{3}$.

Created in 2002, the ACP Recife is one of the successful community programs performed by public institutions that promote physical activities and nutritional guidance in Brazilian cities ${ }^{4}$. It was regulated by Municipal Decree number 19.808 from April $3^{\text {rd }} 2003^{3}$, aimed at taking advantage of renovated public spaces for leisure and health equipment to promote the practice of physical activities and encourage the adoption of healthy eating habits.

Managed by the City of Recife Department of Health, the Academia da Cidade Program includes 42 centers with approximately 170 Physical Education professionals. Other health professionals also participate in the network to perform the program actions. Additionally, it develops projects in Psychosocial Support Centers (PSC), Family Health Units (FHU) and other institutions in the country, guiding physical activities, games and thematic trips. The choice of activities depends on the demand of the community and conditions of the space involved ${ }^{3}$.

This program influenced the creation of other initiatives in the state of Pernambuco and other cities, states and regions of Brazil, such as the Academia das Cidades Program in Pernambuco ${ }^{5}$ and the Academia da Saúde Program from the Federal government $t^{1}$. However, as the entire population benefits from health projects and actions, the opinion of users about the quality of health care is considered to be of key importance when seeking to assess these services ${ }^{6}$.

To understand the reasons for users to go to spaces that promote activities aimed at improving health can help decision-making regarding the provision of such services ${ }^{6}$. As a result, the improvement in health programs can be based on the assessment process, supported by system analysis from the perspective of users, working as a parameter for health actions and policies ${ }^{7}$. In this manner, the free and critical participation of users can contribute to the empowerment of this population group, questions that are essential to enable policies on health promotion, prevention of health problems and disease control ${ }^{8}$. Thus, the present study aimed to analyze users' perception of the Academia da Cidade Program of Recife, in terms of their satisfaction with the offer of services in the ACP, and perceptions of changes associated with quality of life after joining this program.

\section{Methods}

An exploratory and analytical case study ${ }^{9}$ was performed in five out of the 41 ACP Recife centers, considered to be the oldest ones, inaugurated between 2002 and 2004 (Jardim São Paulo, Sítio da Trindade, Boa Viagem, Parque da Jaqueira and Praça do Hipódromo). This study was conducted between August and December 2014. The aim of selecting the five oldest ACP centers was due to the fact that this would guarantee the participation of users who had been on this program for more than five years.

The city of Recife covers an area of $209 \mathrm{~km}^{2}$ and has a population of over 1.5 million inhabitants. Since 1988, its area has been subdivided into 94 districts, in accordance with Decree 14.452/88. For the purpose of planning and management, this city is also spatially divided into six Political-Administrative Regions (PAR), each subdivided into three Micro-regions (MR) that gather districts with greater territorial similarities. In health, each PAR corresponds to a Health District and the distribution and management of centers take place through a coordinating office from each district and one general coordinating office. 
In the present study, individuals who had been participating in this program for at least five years were included in the sample. It should be emphasized that the majority of users in this program were females and that only women met the selection criterion and accepted to participate in this study. Participants were selected intentionally, as researchers were interested in the opinion (action and intention, among others) of some of them ${ }^{10}$, as they are considered to have characteristics that are typical or representative of this population ${ }^{11}$. This study sought to interview users from the oldest centers, as it understood that they could be following the functioning of the program for a longer period of time. This enabled the acquisition of better information about users' perception of actions, improvement in quality of life and satisfaction with the program. The saturation criterion was used to define the final sample size. A total of 28 users aged between 28 and 73 years participated in this study, identified in the body of the text by the number of order of interview (User 1, User 2, User 3 etc.). Interviews were performed by a researcher, taking place at the same center where users performed their activities and lasting 20 minutes each on average.

Interviews are a privileged data collection instrument, as dialogues can reveal structural conditions and systems of values, norms and symbols, while they can represent certain groups in specific historical, socioeconomic and cultural conditions ${ }^{10,11}$. Interviews were conducted aiming to gather information about users' perception of the continuity of the program, the offer of services and the repercussions in their quality of life. Interviews were recorded and subsequently transcribed. Discourse content analysis was performed to identify the categories of analysis and their variables, with the models of analysis of interviews developed by Kvale $^{12}$ used as framework. This author emphasizes five main types of analysis: the gathering of meanings, the categorization of meanings, the structuring of meanings through narrative, the interpretation of meanings, and the ad hoc method of generation of meanings. Among the types described, gathering of meanings was used, as this is considered to be the most adequate technique to achieve the objectives of a study, according to the literature on similar studies ${ }^{13,14}$.

The steps followed for the organization and analysis of interviews were: a) thorough reading of interviews, aimed at understanding the meaning of it all; b) determination of natural units of meaning, as expressed by individuals; c) definition of central themes related to natural units in the simplest way possible; d) questions about the relationship between units of meaning and the research objectives; e) key description of the themes identified in the interviews related to the research objectives ${ }^{12}$.

In this type of analysis, passages from interviews were associated with a specific question from this study and summarized in a table comprised of natural units of meaning of responses from participants on the left column and central themes related to them, i.e. conceptual categories, on the right column, with the key description of the question related to the study following below both (Table 1).

The present study is part of the thesis entitled "Physical Activity Promotion Program: a Study on the Implementation of the Academia da Cidade Program (ACP) in the City of Recife between 2002 and 2014". This study was in accordance with the ethical precepts of Resolution 466/12 of the National Health Council/ National Research Ethics Committee and it was authorized by the Aggeu Magalhães Research Center/Fiocruz Pernambuco Ethics Committee under official consolidated opinion number 656.639/2014. 
TABLE 1 - Gathering of meanings with natural units of analysis, central themes and essential description.

\begin{tabular}{|c|c|}
\hline \multicolumn{2}{|l|}{ QUESTION 4 - Users } \\
\hline \multicolumn{2}{|c|}{ Are the activities provided by the ACP the ones you really wanted to do? } \\
\hline Natural Unit & Central Theme \\
\hline $\begin{array}{l}\text { Yes. The only thing missing is a shelter. There is one, but it's } \\
\text { makeshift. }\end{array}$ & The activities provided satisfy the user. \\
\hline Certainly. I think it could be better. & $\begin{array}{l}\text { Activities provided satisfy the user, but there could } \\
\text { be improvements. }\end{array}$ \\
\hline $\begin{array}{l}\text { Yes, I like to do it. There could be more dancing, there could } \\
\text { be more because time is short. But I like it here. }\end{array}$ & $\begin{array}{l}\text { Activities provided satisfy the user, but there could } \\
\text { be an increase in session time. }\end{array}$ \\
\hline I'd like to do other activities, but these are good. & $\begin{array}{l}\text { Activities provided satisfy the user, but there could } \\
\text { be more variety. }\end{array}$ \\
\hline \multicolumn{2}{|l|}{ Essential Description of Research Question } \\
\hline The a & \\
\hline
\end{tabular}

\section{Results}

After the analysis of discourses of users was performed, the following two categories of analyses were identified: a) User satisfaction with Academia da Cidade Program actions in Recife; and b) Perceptions of changes associated with quality of life after joining the Academia da Cidade Program - Recife.

\section{User satisfaction with Academia da Cidade Program actions in the city of Recife}

Aiming to better understand the relationship between users and ACP, the feeling associated with the structure and actions offered by the program had to be observed.

With regard to the infrastructure of the ACP Recife, we realized that as the program increased (higher number of centers and districts covered), there was a higher level of difficulty to maintain equipment and physical facilities. Until 2008, the ACP included 20 centers. With the partnership with the State of Pernambuco government through the Academia das Cidades Program (ACSP), this number increased to 42 centers, distributed across six health districts which served nearly 30,000 users per month.

When asked about their perception of the quality of the program actions, lack of equipment and maintenance of the physical space were the problems most frequently mentioned by users.

There are not enough sticks. Mattresses are falling apart, their plastic is falling off. There's no way we can exercise with those bottles that drop earth on us. (User 2)

In addition to the partial dissatisfaction with the materials and facilities, the need to search for improvements in the physical activities promoted arose in the discourses. The reports on the activities provided by the program given by users 1 and 6 should be emphasized:

I think there's still much that could be better, when we get to see something different here. There's still a lot missing here for us, especially now that things got worse in terms of teachers and materials... (User 1)

I'd like to have something more intense, something better planned for each user. (User 6)

On the other hand, when asked about the main positive aspects of the program, the majority mentioned the relationship with the teachers. Their good rela- 
tionship was the most frequently reported quality of program professionals.

I like the teachers, they're excellent. We talk a lot with the girls. Just by talking, we can share ideas about life (User 08).

They're all good! The teachers are good because the exercises are good... Teachers are attentive and patient with us. (User 10)

When asked about their personal impressions on the actions provided by the ACP, the perception of users ranged between satisfaction with the activities developed and the indication that improvements should be made in aspects associated with session time and variety of activities:

They're really good classes, especially step and dancing. (User 5)

Yes, they meet my needs. (User 4)

They certainly do. I like them. (User 8)

Yes, I like doing it. There could be more dancing, there could be more because time is short. But I like it here. (User 9)

I'd like to do other activities, but these are good. (User 10)

With regard to the conditions that could prevent or hinder user participation in ACP Recife activities, the majority of interviewees pointed to weather conditions (rain) and health-related issues as relevant for non-participation.

The rain. We can't do the activities when it rains. Or when I'm sick, which is rare. (User 1)

Illness. If I'm ill, I can't come. When I fall and I can't kneel for example, I can't do it, so I don't come. (User 2).

In contrast, there were responses indicating that feeling indisposed to exercise and the need to resolve personal problems out of the community as situations that prevent or hinder participation in activities, as observed in the following reports:

It could be when I'm not feeling well. Or when I have to run some errands, so I can't come. (User 8) [...] Sometimes I'm not feeling well, you know? That's all that stops me! (User 27).

\section{Perceptions of changes associated with quality of life after joining the Academia da Cidade Program in Recife}

When users were asked about "How the program promoted changes in their quality of life", there was an improvement in their perception of health condition.

Health, I'm feeling better! I feel good doing gymnastics, coming to "Jaqueira". When June comes, the party lasts all month long. (User 12).

It works. If it wasn't for them, I'd be sick, I'd stay bome and sick. (User 17)

The increase in the number of possibilities of social interaction was also perceived as a change in participants' quality of life.

It's been a great influence, for better, I'm sure. The willingness, the will to come here, the meetings and friendships. I've made many friends here, you know? True friends. (User 13)

I feel good doing gymnastics and coming to the "Sitio". When June comes, the party lasts all month long. (User 2) 
Additionally, physical activity and healthy eating arose as aspects associated with changes in lifestyle perceived after joining the ACP. When asked about quality of life, there was a convergence of responses of volunteers, associating the term with physical activity and diet:

There was an influence. This influence was great in my quality of life. Just the fact that I wasn't inactive as I used to be, after I joined the Academia da Cidade Program, I felt motivated to ride a bicycle and to do bydrogymnastics. So, I'm a new person in terms of health. (User 1)

Certainly! A lot! Because at first I used to eat more fatty and fried foods, things like this. Now I eat more vegetables and fruits... (User 9).

\section{Discussion}

The users interviewed were dissatisfied with the material used in gymnastics sessions, considering it to be insufficient and inadequate. Regarding program actions, positive and negative perceptions of the intervention of Physical Education professionals in the centers coexisted, as did the impressions on the quality, types, duration and variety of activities developed. Moreover, the discourses indicate that rain, feeling indisposed to exercise and the need to resolve personal problems out of the community are the main conditions that hinder or prevent participation in ACP activities.

The main cause of dissatisfaction among users interviewed refers to the lack of equipment and maintenance of program centers. This perception was also observed among professionals who work in the Academia da Saúde Program in five cities of Recife Metropolitan Area ${ }^{15}$. This lack and inadequacy of resources compromises planning, execution and quality of activities provided by the ACP, which could reflect in the continuity of some actions ${ }^{8,16}$ and interfere with the motivation, adherence and joining of such program by these and other users.

Furthermore, regarding dissatisfaction with the program actions, the discourses point to the need to improve the quality of physical activities offered and adapt both the intensity and planning of actions to different target populations covered by the ACP. Such dissatisfaction requires special attention from the program manager, as it points to the need to adapt program activities to the perspectives of different sub-groups of users, so that the interventions developed are aligned with the meanings and demands from the target population, aiming to enable this program to be more effective ${ }^{17}$.

On the other hand, a good relationship with professors was perceived as a positive aspect by users. The professional-user relationship seems to have been a determinant for joining of and adherence to programs that promote physical activity and health. Studies on satisfaction in Primary Health Care (PHC) showed that users rated relational aspects (service, care, interpersonal communication) better than organizational aspects (physical structure, access to consultations and medication $)^{18,19}$. It should be emphasized that users' perception of health services enables their relationship with professionals, humanized care and satisfaction with health care to be assessed ${ }^{20}$.

In a study performed with the objective of observing the perception of users and professionals when assessing quality of public health services, Martins et al. ${ }^{20}$ showed that a good professional-user relationship is required to guarantee the quality of PHC services, among other things. Moreover, users' discourses pointed to the coexistence of satisfaction with the activities provided and the negative perception of the duration and contents of the actions developed in the centers. With regard to the dissatisfaction with such duration and contents, it should be 
emphasized that not directing activities towards user expectations can reduce adherence to program ${ }^{21}$, in addition to restricting the possibilities of potential users to join it and showing managers' lack of concern about the interests of the target population of such intervention ${ }^{15}$.

Apart from revealing the positive and negative aspects of the actions offered by the ACP, users pointed to the main conditions that could prevent or hinder their participation in program activities. Climatic and health aspects stood out among them. Several studies have indicated weather conditions, especially the presence of rain, as one of the main barriers to access to programs of physical activity in public squares and parks ${ }^{20,22}$. Additionally, studies also point to health problems as an important cause for discontinuing the practice of physical activity ${ }^{21}$.

The ACP Recife originated from the need to promote health prevention and promotion actions. To achieve this, the general objective was to contribute to the promotion of collective health in public spaces, aiming to improve the quality of life of Recife residents ${ }^{3}$.

The term "quality of life" includes aspects associated with the subjective dimensions of individuals, considering that the idea of well-being must include everyone, due to their beliefs, values and ideologies, even if a consensual definition of "quality of life" cannot be reached and thus represent it in its totality. For some, quality of life carries an eminently human notion, similar to the level of satisfaction found in family, love, social and environmental life and existential aesthetics itself ${ }^{23}$.

Thus, even without one general concept, the idea of quality of life is largely used by individuals to define their needs and what they lack. When ACP users were asked "How has the program promoted changes in quality of life?", discourses that point to an improvement in the perception of their health condition were more frequent. Considering that the majority of participants were aged more than 60 years and that the health condition perceived was characterized as an important indicator of mortality ${ }^{24}$ and reduction in functional capacity ${ }^{25}$, the perception that ACP activities improved their health condition can be characterized as a positive influence of program actions on one of the aspects of quality of life in this population group.

Participants perceived the program as a space that enables social interaction and, consequently, as something that has a positive impact on quality of life. The perception that social interaction is one of the benefits promoted by physical activity programs was identified by Guarda et al. ${ }^{15}$ in a study conducted with Physical Education professionals who work in community programs of health promotion. In another study, performed with users of the Academia da Cidade Program - Recife ${ }^{4}$, social interaction was found to be one of the reasons to participate in the program.

Furthermore, participants also perceived the change in lifestyle associated with the inclusion of physical activity and healthy eating as positive influences of this program on their quality of life. Some studies point out that quality of life can be influenced by aspects of daily living ${ }^{26}$ or individual behavior that include the practice of physical activities, alcohol and tobacco use and eating habits ${ }^{27}$.

In a study on the perception of quality of life of women participating in groups of physical activities, such perception was found to be directly associated with aspects of their daily living, such as the greater ease to perform activities of daily living, the full capacity of self-care, the general feeling of good health, the perspective of a long life and family support ${ }^{26}$.

Diet is a theme that has been explored in ACP actions through lectures and individual counseling (when required) by nutritionists who are part of the city's health network. In a study on the perception of quality of life of users of a Family 
Health Support Center, when asked about their quality of life, participants' responses converged and associated the term with physical activity and diet ${ }^{28 .}$

During interviews, the influence of the ACP Recife on users' quality of life is associated with the activities provided and the relationship between professionals and users. This seems to be an indication that the offer of program services has become closer to the needs of the community. Additionally, this should be emphasized when such type of program is assessed, as the search for quality is required in public health services, due to the great social inequalities; living and health conditions of the population; inadequate allocation of resources; inefficiency; increasing expenses; and inequality of users' conditions of access ${ }^{29}$. The perception of users can interfere with accessibility, formation of bonds and the resulting horizontality of care, aiming to have an effect on the team's capacity to coordinate health care ${ }^{30}$. Thus, one of the key aspects of quality of service refers to user satisfaction and the quality that this satisfaction effectively and positively brings to their quality of life.

Although users indicated dissatisfaction with the lack of materials, lack of diversity/variety, and the duration and type of activities provided by the ACP Recife, the perception of improvement in health, the pleasure of physical activity practice, the social interaction and the good relationship with the professionals involved can be characterized as factors that contribute to adherence to this program.

However, it should be emphasized that the need to constantly evaluate ACP actions, aiming to improve its offer, whether in terms of variety of activities or increase in duration of sessions. Improvements in infrastructure have been suggested by users, such as the coverage of centers, as weather conditions were mentioned as a barrier to participation in this program, apart from feeling indisposed due to opportunistic diseases.

\section{Authors' contributions}

Wallacy Milton Nascimento Feitosa of: project design; collection, analysis and interpretation of data; writing the article and final approval; Flávio Renato Barros da Guarda: collection, analysis and interpretation of data; wording of artigoe final approval; Lisandra Maria Konrad: Article Writing and final approval; Widjane Sheila Ferreira Goncalves Article Writing and final approval; Petronius José de Lima Martelli: Writing the article and final approval; José Luiz do Amaral Araújo Júnior belt: project design, writing the article and final approval.

\section{References}

1. Malta DC, Silva MMA, Albuquerque GM, Lima CM, Cavalcante T, Jaime PC. A implementação das prioridades da Política Nacional de Promoção da Saúde, um balanço, 2006 a 2014. Cien Saude Colet. 2014; 19(11): 4301-12.

2. Sallis JF, Cervero RB, Ascher W, Henderson KA, Kraft MK, Kerr J. An ecological approach to creating active living communities. Rev Public Health. 2006; 27(1): 297-322.

3. Recife. Secretaria Municipal de Saúde. Programa Academia da Cidade do Recife. Nota Técnica, 2010.

4. Hallal PC, Tenório MCM, Tassitano RM, Reis RS, Carvalho YM, Cruz DKA, et al. Evaluation of the Academia da Cidade Program to Promote Physical Activity in Recife, Pernambuco State, Brazil: perceptions of users and nonusers. Cad Saude Publica. 2010; 27(1):70-8.

5. Pernambuco. Secretaria das Cidades. Decreto $N^{\circ}$ 31.140. Institui o Programa Academia das Cidades. Recife: Diário Oficial do Estado de Pernambuco, 2007.

6. Jesus PBR, Carvalho DV. Percepção de Usuárias de unidade de saúde da família sobre a assistência à saúde: uma contribuição da enfermagem. Rev Min Enferm. 2002; 6(2):48-56.

7. Moimaz SAS, Marques JAM, Saliba O, Garbin CAS, Zina LG, Saliba NA. Satisfação e percepção do usuário do SUS sobre o serviço público de saúde. Physis. 2010; 20(4):1419-40. 
8. Cotta RMM, Schott M, Azeredo CM, Franceschini SCC, Priore SE, Dias G. Organização do trabalho e perfil dos profissionais do Programa Saúde da Família: um desafio na reestruturação da Atenção Básica em Saúde. Epidemiol Serv Saúde. 2006; 15(3): 7-18.

9. Yin RK. Estudo de caso: planejamento e método. 3. ed. São Paulo: Bookman, 2005.

10. Navarrete MLV, da Silva MRF. Introducción a las Técnicas Cualitativas de Investigación Aplicadas en Salud. Barcelona: Universidad Autónoma de Barcelona, 2006.

11. Minayo MCS. O desafio do Conhecimento: pesquisa qualitativa em saúde. São Paulo: Hucitec, 2004.

12. Kvale S. Interviews: an introduction to qualitative research interviewing. Thousand Oaks: Sage, 1996.

13. Guarda FRB, Silva RN, Feitosa WMN, Santos Neto PM, Araújo Júnior JLAC. Caracterização das Equipes do Programa Academia da Saúde e do seu processo de trabalho. Rev Bras Ativ Fís Saude. 2015; 20(3): 638-49.

14. Santos FAS. Política de Saúde em Pernambuco e os Novos Arranjos Jurídicos: processo, definição de prioridades e evidências [tese de doutorado]. Recife: Centro de Pesquisas Aggeu Magalhães, Fundação Oswaldo Cruz; 2014.

15. Guarda FRB, Silva RN, Feitosa WMN, Farias JM, Santos Neto PM, Araújo Júnior JLAC. Self-perception of the objective, object and work products of Physical Education Professionals belonging to the Academia da Saúde Program. Rev Bras Ativ Fís Saúde. 2016; 21(5): 400-9.

16. Werneck MAF. Protocolo de cuidados à saúde e de organização do serviço / Marcos Azeredo Furkim Werneck. Belo Horizonte: Nescon/UFMG, Coopmed; 2009.

17. Cohen-Mansfield, J; Marx, MS.; Biddison, JR.; Guralnik, JM. Socio-environmental exercise preferences among older adults. Prev Medic. 2014: 38. 804-11.

18. Lima-Costa MF, Loyola Filho AI. Fatores associados ao uso e à satisfação com os serviços de saúde entre Usuárias do Sistema Único de Saúde na Região Metropolitana de Belo Horizonte, Estado de Minas Gerais, Brasil. Epidemiol. Serv. 2008; 17(4): 247-57.

19. Machado NP, Nogueira LT. Avaliação da satisfação dos Usuárias de serviços de Fisioterapia. Rev. Bras. Fisioter. 2008;12(5):401-08.

20. Martins LFV, Meneghim MC, Martins LC, Pereira AC. Avaliação da qualidade nos serviços públicos de saúde com base na percepção dos usuários e dos profissionais. RFO. 2014; 19(2):151-58.

21. Cardoso AS, Borges LJ, Mazo GZ, Benedetti TB, Kuhnen AP. Fatores influentes na desistência de idosos em um programa de exercício físico. Movimento. 2008;14 (1): 225-39.

22. Silva DAS, Petroski EL, Reis RS. Barreiras e facilitadores de atividades físicas em frequentadores de parques públicos. Motriz. 2009; 15(2): 219-27.

23. Seidel EMF, Zannon CMLC. Qualidade de vida e saúde: aspectos conceituais e metodológicos. Cad Saúde Pública. 2011; 20: 580-88.

24. Borges AM, Santos G, Kummer JA, Fior L, Molin VD, Wibelinger LM. Autopercepção de saúde em idosos residentes em um município do interior do Rio Grande do Sul. Rev. bras. geriatr. gerontol. 2014; 17(1): 79-86.

25. Alves LC, Rodrigues RN. Determinantes da autopercepção de saúde entre idosos do Município de São Paulo, Brasil. Rev Panam Salud Publica, 2005; 17 (5/6): 333-41.

26. Arcanjo GN, Valdés MTM, Silva RM. Percepção sobre qualidade de vida de mulheres participantes de oficinas educativas para dor na coluna. Ciênc. Saúde Coletiva. 2008; 13(2): 2145-54.

27. Organização Pan-Americana de Saúde. Municípios e comunidades saudáveis: guia dos prefeitos para promover qualidade de vida. Brasília: OPAS; 2002.

28. Souza FLD, Chacur EP, Martins RCC, Silva LAM, Góes RWL, Villela WV. Percepções sobre qualidade de vida das usuárias de um Núcleo de Apoio à Saúde da Família. Investigação. 2013; 13: 34-8.

29. Fadel MAV, Regis Filho GI. Percepção da qualidade em serviços públicos de saúde: um estudo de caso. Rev Adm Publica. 2009; 43(1): 07-22.

30. Savassi LCM. A satisfação dausuária e a autopercepção da saúde em atenção primária. Rev Bras Med Fam Comunidade. 2010; 5(17): 3-5.

CORRESPONDING AUTHOR

WALLACY MILTON DO NASCIMENTO FEITOSA

wallacy.feitosa@gmail.com
Rua dos Operários, 321 - apto. 1503 -

Torre. Recife, PE, Brazil. 50.710-170

Telephone: +55 (81) 99626-0024/ +55

(81) $99631-1363$ 